\title{
Bálint Sándor
}

\section{A kultúra mindenkiben}

\author{
Sándor Bálint \\ The Culture in Everybody
}

Összefoglalás

Ez a tanulmány arra a kérdésre keresi a választ: mit jelent egy modern társadalomban az ember a kultúrában, a kultúra az emberben? Mi köze van embernek a kultúrához? Füződik-e érdeke az embernek ahhoz, hogy egyéni életvilágán, politikán, gazdálkodásán túl kultúrával is foglalkozzon akkor, amikor a megélhetés vagy a meggazdagodás gondjaival van elfoglalva? Igaz-e még, vagy már, hogy jól csak müvelt és erkölcsös nép élhet? Szükséges-e, hogy a polgár ne csak tulajdonos, ne csak gazdag, de müvelt ember is legyen? Ha azt a mesterséges környezetet nevezzük kultúrának, melyet az emberiség hoz létre és melyben az ember él, ami nem más, mint az anyagi - szellemi értékek összessége, akkor ez mostanában a modernizációban, modern társadalomépitésnek és a tradicionális társadalmak tagadásának rendkívül sokféle folyamatainak küzdelmében megy végbe. Ez az a környezet ahol a közelítö káoszban elkezdödik a harc az új világért, új rendért, az új rendszerekért.

Kulcsszavak: kultúra, demokrácia, múvelődés, érdek, értékek

\section{Summary}

The present study searches for the answer to the question: what man means in culture and what culture means in the modern human world. What have people got to do with culture? Does man have any interest in dealing with culture beyond the individual life, politics, and management in those days when man deals with living or getting rich? Is still or yet true that only the educated and virtuous humans should live well?

Keywords: culture, democracy, civilization, interests, values

\section{BEVEZETÉS}

„Mindent kitaláltunk már, kivéve azt, hogy hogyan kell élnünk." /Jean-Paul Sartre/

A modernitás szinte teljesen új gondolkodás, új tanulási és cselekvési múfaj, nyitva a világra van min gondolkodni, cselekedni, melynek megteremtésében vállalnak szerepeket az emberek, kultúrák, intézmények. Az emberiség és a világ szerkezeti, a tudomány pedig paradigma váltásában él. Tradicionális - röghöz kötött - társadalmak modern rendszerekké, fogyasztói civilizációkká szerveződnek.

Célok, érdekek, értékek, magatartás és tudatformák, közösségek, intézmények nagy átalakulásban vannak. Kultúrák, a politikai, gazdaági, társadalom-lélektani, morális környezet, civilizációs pozitív és negatív hatások (siker és kudarc), modellek alá kerülnek. Kérdések - válaszok, új kategóriák fogalmazódnak: mi történik velünk magyarokkal, parasztokkal, munkásokkal, 
pedagógusokkal, politikusokkal, orvosokkal, a szellemi termelési mód (az értelmiség) életvitelével? Akartuk-e, hogy rendszerváltás legyen és így legyen?

Milyen tanulságok vonhatók le a magyar és nem magyar - amerikai - rendszerváltás tapasztalataiból? Merre tart Magyarország és megyénk a Jászkunság? Mi igazán most a fontos: kultúrában, politikában, gazdálkodásban, oktatásban, egészségügyben? Megelőzhetné-e nálunk az erkölcs, a szabadság, mint erkölcsi közjó a politikát, mint az USAban? Ezekről a témákról szól a tanulmány I. része. Közkincsé kellene tenni néhány nagy elme múvét a társadalomról, a kultúráról: Andorka Rudolf ${ }^{1}$, Zygmunt Bauman, Nyelvészek - szótárírók, Csányi Vilmos, Vitányi Iván, Hankiss Elemér, Csepeli György, Heller Ágnes, Bozóki András, László Ervin. Erről szól a tanulmány második része. Többféle vélemény fogalma, kategóriája nyer itt értékközvetítést a kultúráról. Számos igen értékes elemzés van a kultúrák fogalmáról, a kultúrák szerepéről, funkcióiról, a kultúrákat befolyásoló, meghatározó objektív - szubjektív, anyagi és szellemi tényezőkről, köztük az életmódról, a kultúrák intézményeiről, a kulturális evolúció és szocializáció fázisairól. A kulturális értékek érdekek, az identitás és a mentalitás világáról.

\section{EMBER A KULTÚRÁBAN}

Tanulságok: kérdések - válaszok - vélemények, sikerek és kudarcok rendszerváltásokról, családtól - világváltásig, céltól az eredményig, szándéktól a következményig, van min gondolkodni-cselekedni.

1. Az USA-ban az erkölcs megelőzte a politikát (Csizmadia Ervin)a politika az erkölcsre épült, a szabadság lett a közjó, a jó kormányzás. Az állam, a család, a magántulajdon tisztelete jog és kötelességgé szerveződött. Az igazság-osság nemcsak hívószó lett, hanem alkotmányban előírt követelmény, a mindennapi élet normája. A társadalmi, politikai mezőben az ember a hatalom és etikai vákuumot a megfelelő szocializáció - integráció, a jó önkormányzás révén nem engedte kiszélesedni se a korrupció se a mohóság magatartás világában. Magyarországon nem volt ilyen stratégia, taktika és etika. A politikai hatalom mélyén mély etikai vákuum tátong. Ugyanakkor nagyon sok ember jó ember, nem fél tisztességesnek lenni, tudja miért és hogyan lehet tisztességes.

2. Az összegzésben már érintettük, szükséges a világváltás, világlátás, nyitva a világra, kellett a rendszerváltás! Az állampolgárok többsége akart vagy nem akart rendszerváltást! A kitűzött célok, eszmék, követelmények, alapvető értékek nem voltak jók (Tamás Gáspár Miklós). Morálisan tarthatatlannak érzem a helyzetet (Kupa Mihály). Alapértékek a szavahihetőség, a tisztességes üzleti magatartás, az együttműködés teljesen hiányzik a szótárból. A rendszerváltó garnitúra tudás-hiánya és / vagy mohósága, saját népének cserbenhagyása miatt a magyar rendszerváltás banán-köztársaságos rendszerváltás volt (Petrasovics Anna). Spíró György: Bekerítve. „A szocialista gazdaság lehetőségeit erősen korlátozottnak tartottam, de abban nem hittem, hogy a kapitalizmus nálunk lehetséges balkáni vagy dél-amerikai formája szellemi és lelki felszabaduláshoz, a vállalkozás valódi szabadságához, általános jóléthez és igazságos társadalomhoz vezetne". ${ }^{2}$ „Rendkívüli igazságtalan társadalmak jöttek létre Kelet-Európában, óriási társadalmi feszültségekkel és középkorias hiedelmekkel; nem jobb a helyzet, mint volt a harminca években; a jelenlegi gazdasági világválságot is csak a harmincas évekhez lehet hasonlítani." Az itt idézett vélemények a rendszerváltásról jelzik, mi történt velünk és azt is, hogy miért hagytuk, hogy így legyen? 
3. A rendszerváltás, a válság tanulsága: a politikának, a hatalomnak elsőbbséget kell adni nemcsak az erkölcsnek, hanem a piacnak és a piaccal szemben, a munkának pedig, a tókével szemben, figyelembe véve, hogy a munka nagyon fontos, de nem érték, hanem a munka az érték forrása - szülőhelye (Marx). Az érték ott és akkor jön létre, ha az állandó tôke és a változó tőke - az ember (a munkás) - értéket, új értéket, értéktöbbletet hoz létre a hozzáadott szellemi, fizikai értékekből. Számtalan munkát el kell végeznie az embernek (közjavat, közérdeket, közhasznú munkát, szolgálatot, aki, ami azzal a tevékenységgel nem hoz létre értéket. A munka alapú társadalomépítés fogalmát, világát, nem helyes azonosítani a tudásalapú értékracionális társadalom fogalmával. Például: ha egy településen túl sokat végeznek közhasznú-, közmunkát, de kevesen hoznak létre új értéket, értéktöbbletet, ott, akkor nem lesz nagyobb a torta, bárhogyan is osztják el, elosztani pedig csak azt lehet, amit megtermelünk, takarózni addig kell, amíg a takarónk ér. A munkának elsődlegességet kell adni a tőkével szemben, azért is mert a tőke forrása is a munka, az értéket - értéktöbbletet teremtő munka. Az embernek érdeke fúződik az anyagi - szellemi értékteremtő - racionális munkához oly mértékben és minőségben is, hogy érték a mérték. Tehát a gazdaságnak és a politikának, a kultúrának is vissza kell nyúlnia az érdekteremtő, értékvédő, értéktisztelő munkához, versenyhez, szolidaritáshoz, a társadalmi igazsághoz - igazságossághoz (miként Mátyás királynak) - tisztességhez, hogy miként legyek ÉN tisztességes, ha kiterítenek úgy is. A pénzügyi piacok kapzsisága és irracionális vadhajtásaik a kaszinókapitalizmusba torkoltak. A gazdagok gazdagabbak lettek, a szegények szegényebbek, az ország harmada rettenetes körülmények között él szépségével és tragikus részével együtt, miközben a középosztály vásárlóereje csökkent, tagjaik közül sokan eladósodtak, a bankvezetők pénzzel tömik ki zsebeiket.

4. Milyen tények, érvek lehetnek s szólnak a mellett, hogy mi köze van a modernizálódó embernek a kultúrákhoz?

- Közös kincsé kellene tenni néhány nagy ember múvét, tanulmányát alkotását a kultúrákból, kultúrákról.

- Tudatosítani, elfogadtatni emberek-kel, hogy értékek, kultúrák honnan erednek, honnan származnak, mit jelent a kultúra, mint anyagi és szellemi, testi, lelki, szellemi, termelési mód, mint mesterséges, emberiség által létrehozott olyan környezet, melyben az ember él, s melyben a gyermek felnő, felelős önálló, autonóm, szabaddá, személyiséggé érik, válik de esetleg mégis láncon van, az emberembernek farkasa, kulturálatlan, múveletlen, faragatlan marad? Mert, hogy erre szocializálódott. Mert így integrálódott: nevelés, tanítás, fegyelmezés, elismerés révén.

A közigazgatás pedig büntet, kilakoltat, megadóztat, kitüntet.

Köze van az embernek ahhoz is: melyik kulturális vagy más tényezőnek - politikánk, gazdálkodásnak, oktatásnak, gyógyításnak, szociális ellátásnak, tudománynak, sportnak stb. mekkora súlya, ereje van az emberek, családok, települések életébe. Nagyon fontos mit hordoz életében az ember, az állampolgár? Milyen munkát, tudást, tudatlanságot, magatartást, kultúrát, politikát, tudományt, egészséget, lelkiséget, sikereket, kudarcokat, teljesítményt, jövedelmet, erkölcsöt vagy ezek hiányát. A nevezett anyag- és szellem-, lélekfajták mozgásformák keresztül-mennek az emberek fején és kezén, megismerjük 
megtanuljuk őket, szereplőjük, szerzőjük lehetünk, ha hozzájuk férünk, ha azonosulunk velük. Egyéne, családja, közössége, társadalma választja az embernek, mit hordoz létében, sorsában ezekből az anyagi, szellemi javakból, hogy mely értékekhez lesz köze, - kanász marad-e az, akinek nevelője kanász, messze esik-e alma a fájától, mi leszel, ha nagy leszel, királyok, hercegek, grófok születnek-e, királlyá születik-e valaki vagy válik azzá, ezektől is függ, hogy mikor, milyen köze lehet, lesz kultúrájának.

- Köze van az embernek az Európai Unióhoz, ami számunkra nemcsak gazdasági földrajzi térség, hanem értékközösség is. $A z$ EU pedig olyan szerződés, amelynek tagjait érdekek és értékek egyaránt összekötik. llyen értékek: szabadság, egyenlőség, testvériség, rend, béke, nyugalom szolidaritás, jólét, biztonság. Az EU fő politikai értékei: pluralizmus, jogállamiság, emberi jogok. A többségnek biztosan van oka, van köze, hogy olyan „értékszerkezetet” hozzon létre, mely közjóként múködik az emberben. Ám szükséges az erős nemzeti - jóléti állam is, mert csak az tud középosztályt is teremteni (Pogátsa Zoltán). Érdekli az embereket nagyon: lehetséges-e nyugatias (jóléti demokratikus - igazságos) fejlődés, keleties értékrenddel? Diktatórikus, alá-vetettségi, eltorzult magyar alkattal, olyan elittel, mely ha győz, mindent visz, maffiózó és mohó, privatizál, aki hazudik és lop is, mondja: „megöllek”, „kinyírlak”, „ne szólj vissza te ember". Tehát megfelelő kultúra nincs minden emberben, nincs mindegyik szervezethez, intézményhez (holokauszt, fasizmus, bolsevizmus, vörös terror, fehérterror, terrorizmus).

\section{KULTÚRA AZ EMBERBEN. KULTÚRA MINDENKIBEN.}

Közkincsé kellene tenni néhány nagy ember múvét a társadalomról, a kultúráról: Andorka Rudolf, Zygmunt Bauman, nyelvészek szótárírók, Csányi Vilmos, Vitányi Iván, Hankiss Elemér, Csepeli György, Heller Ágnes, Bozóki András, László Ervin. Erről szól a tanulmány II. része. Többféle vélemény fogalma, kategóriája nyer itt értékközvetítést a kultúráról. Számos igen értékes elemzés van a kultúrák fogalmáról, a kultúrák szerepéről, funkcióiról, a kultúrákat befolyásoló, meghatározó objektív, szubjektív, anyagi és szellemi tényezőről, köztük az életmódról, a kultúrák intézményeiről, a kulturális evolúció és szocializáció fázisairól, a kulturális értékek - érdekek, az identitás és a mentalitás világáról.

\section{Zygmunt Bauman a kultúráról $\left.\right|^{3}$}

Warszava szociológusa új könyvet irt az Általános szociológiáról elméletet és fogalmi apparátust a társadalmi valóság megértéséhez. Múve egy összefüggő társadalomszemlélet szerves alkotó része: a társadalom, a társadalmi lét, a tudás, a társadalmi struktúra, az ember és a társadalom, a társadalmi tagozódás rétegződés, a társadalmi fejlődés, a társadalmi környezet, a kultúra stb. szociológiai kérdéseiről, kategóriáiról, értékeiről, problémáiról. Itt most csak a kultúra fogalmáról, a kulturális élet jellemzőiről írunk vázlatos képet.

\section{A kultúra fogalma}

Azt a mesterséges környezetet, amelyben az emberi élet folyik, melyet az egymást követő nemzedékek hoztak létre, nevezi - nevezzük kultúrának. A kultúra a társadalmi alkotások objektivált elemének összessége, amelyek számos csoport számára közösek és objektivitásuk következtében a térben alakultak 
ki és képesek a térben, $s$ időben kiterjedni. $A$ kultúra olyan részekből áll melyek a) társadalmi alkotás elemei, b) ezek az elemek objektiváltak, c) ezeknek az elemeknek tartósnak is kell lenniük, d) képesek a térben - időben kiterjedni, átadhatók más embereknek.

Kultúra: munkaeszközök, szervezet - jogi előírások, erkölcsi normák, szokások, képességek, múvészet, tudomány, vallás, filozófia, a kultúra magva a kiválasztott értékek együttese, kultúra az emberi közösség „kollektív” emlékezete, a tanulás, nevelés, a kultúra készen talált valóság, objektív és anyagi tény, földrajzi-, vízi-, túzi-, stb. energia.

Az emberi - társadalmi kultúra sajátosságai:

- A kultúra az, ami megkülönbözteti az embert az állattól

- A kultúra az emberi közösség „kollektív emlékezete", tanulási folyamat

- Az elsődleges szükségletek kielégítésének módja, tanulási folyamat eredménye

- Embernél a tapasztalatok feldolgozása folyamatos legyen

- Az új egyedek számára a társadalmi kultúra készen talált valóság, objektív és anyagi tény, amelyekben a változók mind meghatározott éréket öltenek, például a javak elosztásánál.

- Az emberek állandóan megváltoztatják környezetüket és növelik anyagi készleteiket

- Az emberiség el is különül egymástól, saját történetet, saját kultúrát él, így sokféle kultúra van, sokféle nyelv - beszéd van, „egyének fölötti” léte van a kultúrának.

- Az emberi életmód, az emberi élet, a kultúra terméke, a kulturális program eredménye.

\section{A kultúra fogalma az Akadémiai Magyar} Értelmező Kéziszótár nyelvészeinek véleménye szerint. ${ }^{4}$

- Kultúra

1. Az emberiség által létrehozott anyagi és szellemi értékek összessége. A múvelődésnek valamely területe, valamely korszakban, valamely népnél való megnyilvánulása (a görög kultúra, a magyar kultúra) a szellemi javak, múveltségi színvonal.

2. Valakiknek, múvelt volta, múveltsége (politika, gazdálkodás, múvelés)

3. Valaminek kulturális volta (a viselkedés kultúrája)

4. Tudományos termelés, múvelés (növények kultúrája)

- Kultúrálatlan, múveletlen, faragatlan

- Kulturális, a kultúrával kapcsolatos Pol. Tört. - forradalom, valamely ország múveltségi színvonalának nagyfokú, rohamos emelkedése pl. Kínai Népköztársaságban, az 1960-as években

Kulturált: csoport, egyesület, egyezmény, kulturált élet, ember, érték, forradalom, fölény, kulturális harc, ház, művelődési ház, múvelődési otthon, igény, intézmény, kapcsolat, az európai - közösség, kulturált mérnök, műsor, kultúrműsor, nemzet, nép (a kun nép, a jász nép) növények, nyelv, kultúros, kultúrfelelős, kultúrház vezetője, verseny.

A kultúra fogalma, terjedelme komplex, sokféle kategóriával terhelt, a kulturális élet magában foglalja a kulturális produkció olyan elemeit, mint: az esztétikum, a művelődés, az esztétikai élmény, katarzis, megvilágosodás, kikapcsolódás szórakozás, munka és a pihenés. Szinte lenyúgöző az emberre nézve az az óriási anyagi szellemi érték amit az ember az emberiség a kultúrában létrehozott, de vajon 
elégedettek lehetünk-e azzal, hogy milyen ma a kultúra mindenkiben, hogy mennyi ember kulturált - múvelt $s$ mennyi a kulturálatlan - múveletlen, faragatlan vétkes, búnös ember, aki öl, lop, hazudik, csal, megalázó, korrupt, terrorista - és ha az, miért az?

\section{Csányi Vilmos, A kultúra mindenkiben!}

A kultúra és az emberi viselkedés.

A kultúra evolúciós, biológiai, genetikai, kulturális rendszer ${ }^{5}$, szociális rendszer. Kultúrák képesek közösségeket létrehozni, kultúra alapja a szabálykövetés, kultúra, gének és az ember, a modern társadalom kultúrája - ilyen gazdag, ilyen értékes kategóriáinak tárháza ennek a nagy magyar etológusnak, viselkedés tudósnak. Kultúra és az emberi viselkedés ilyen híres egyetemi tanárának. Köszönöm, köszönjük.

A kultúra fogalma. A kultúra a társadalomtudományi tábor számára meghatározott viselkedési mintákat tartalmaz, és meghatározott embercsoportokat különböztet meg, s tárgyak formáit, történetileg szelektált ideákat, értékeket. A kultúrák egymás utáni nemzedékek útján replikálódnak, funkcionális kapcsolatban lévő, adott közösség viselkedésformák populációja. A kultúra a már felsorolt rendszerek összessége, más és más a tradicionális (a régi) és a modern társadalmi rendszer kultúrája.

A kulturális evolúció, kulturális rendszer, viselkedése megjósolható modellezhető, élő és élettelen komponenseit megújítja, egyedek elpusztítását újak születése pótolja. A tárgyakat megújítják, a tanítás - tanulás kulturális örökítő mechanizmusai révén átkerül a következő generációk agyába és folytatandó életükbe.

Az emberi kultúrák a szociális vonzódás, a kommunikációs kényszer és a tárgyszeretet által folyamatosan múködtetett funkcionális szabályrendszerek. A kultúra alapja a szabálykövetés, ha megtartod a szabályt, a szabály megtart téged. A nyelv maga is általános kommunikációs evolúciós részrendszer. Ide tartoznak az emberi kapcsolatokra vonatkozó szabály-rendszerek, a tárgyak elóálítására használatára, cseréjére és termelésére vonatkozó szabályok és a kultúra keletkezésére, értékeire, működésére, történetére vonatkoznak, az erkölcsi elvek követése, értékkategóriák elfogadása, a moralitás téridőben változik, a szocializálódás folyamata is átalakul. Az ember biológiai tulajdonságai alapján szociális "társas” lény, amely evolúciójának egy szakaszán a kultúra megjelenésével társadalomba szerveződött. (A horda, a törzs, a főnökségek, az állam). A "társadalmi" fogalom éppen a kultúra szervezőhatását fejezi ki, ez a kultúra egyik funkciója. Például: a gyermeknevelés a kultúra, szervező - formáló hatása révén, a szeretet, az ölelés, az együttes élmény útján segíti a gyermek „társas" lénnyé szerveződését. Figyelembe véve azt, hogy az ember alapjában véve se nem jó, se nem rossz, a kultúra (nevelés) teszi ezzé vagy azzá, de maga a jó és rossz fogalma is mindig, kultúrafüggő, társadalmi, kultúrafüggően változik.

A kultúra evolúciós fázisai ${ }^{6}$

Fontos: meg tudjuk különböztetni a biológiai, organizációs rendszereket a kulturális rendszerektől, ha felismerjük funkcióit. A kulturális evolúció első fázisának a csoporttársadalmak korát tekintjük. Itt az evolúció alanyai a csoportstruktúrák, a csoportorganizmusok voltak, a szelekció az egész kultúrát érintette nemcsak egy kiválasztott jegyet? Vitatott volt itt az egyfajta genetikai determinizmus és az ideák szükségessége a vadászat, halászat, gyűjtögetés, a ragadozók elleni védekezésben. Továbbá a csoportidentitás elfogadása. 
A kultúra 21 különböző eszközt használt, klánok, törzsek kialakulása, javak, leányok és ideák cseréje, megjelenik a „jóo és "rossz" cseréje, ezek pedig, a mítoszok melyek segítenek fenntartani az adott szociális struktúrákat. A második fázis a csoportstruktúrák fejlődése: a tömegtársadalmak megjelenése: városok, államok, hadseregek, pártok, nagy vallások, nagy vállalatok, ideák versenye, cseréje, az embereket a csoportok kohéziója és ideái egyesítik, az ideák fennmaradását a szocializáció, a korai tanulás, az erős tradíció tette lehetővé! Az ideákat, mítoszokat a tudomány, a gyakorlat ideáival is egyeztetni kell. Az ideák csoportszervező erőként müködnek, megjelenik a propaganda, a média. A modern ember elbizonytalanodása, értékvesztése az ideák szelekciójával magyarázható, s azzal, hogy a globális egész elvesztette harmonizáló, szelektáló összefoglaló szerepét. "Minden széttört, szétesett” (Ady). Konfliktusok, elidegenedés, háborúk, vérbosszúk, népirtások, atomizálódás megannyi veszélyes átalakulási, de tanulságos következménye az emberiségben képződő kulturálatlanságnak, műveletlenségnek, erkölcsi romlottságnak, a tízparancsolat tagadásának.

\section{Hankiss Elemér: ${ }^{7}$}

Két gyökeresen más kultúra áll itt egymással szemben, a tradicionális, a régi társadalom kultúrája, a hagyományos európai civilizáció és az új, a most kialakuló modern fogyasztói civilizáció alapértékei, magatartásformái, eszméi, kultúrája - kultúrái - a személyiségformálás két egymásnak ellentmondó, modellje. Ez a nagy társadalmi átalakulás más módon alakítja az embert. Látnunk tudnunk kell mire, hogyan szocializálja az emberek millióit, célok, értékek, magatartásformák hagyományokban, újdonságokban megütköznek egymással. A hagyományos társadalmakban a hagyomány volt az igazi érték ( $p l$. a Lehel kürtje), ma az újdonság az (pl. a Hútőgépgyár- porszívógyár). Ez a kor a keresés kora, a pusztulás (sok üres kert, sok üres ház) és a megújulás (TV-gyár, új híd, Agora - Aréna stb.) az átmenet (rendszerváltás) az élet intenzitásának, a ki és a bevándorlásnak a kora, az énépítés és a szabadság (a szabadság melankóliájának /Lengyel László/) kora. Vagyis Emberlét a fogyasztói civilizációban, melyben mindent kitaláltunk már, kivéve azt, hogy hogyan kellene - jól, igazságosan, tisztességesen, biztonságban - élnünk (Sartre).

\section{Vitányi Iván. A modern társadalom} kultúrája.

Új társadalom - új szemlélet. ${ }^{8}$ vélemények...

Ez a mú nagyon értékes kísérlet az emberi világ, az emberi kultúra új jellemzőinek, elemzésére. Azt bizonyítja, hogy a XX. század utolsó harmadában gyökeres és átfogó változások indultak el az emberi élet minden terültén: a gazdaságban, a társadalmi együttélésben, a kultúrában, a politikában és a mindennapi életben. Kihívások, hálózati szerveződések, forduló pontok: világszerkezeti és tudományos paradigmaváltás, információs társadalom, tudásalapú társadalom, világtotalitarizmus, globalizáció - univerzitás, zártság és nyitottság (kivándorlás és bevándorlás) világszabadság, szabad lettem s félni kezdtem indult el az emberi élet minden területén.

Kultúra mindenkiben? Európa központi részén hetven éve béke van, a világ tanult a második világháborúból, még kitart az egyensúly, a kultúrából is lassan kikophat milyen szörnyű a háború nincs háború népirtás nélkül - féltem közel volt hozzánk a délszláv háború, Szíriában és máshol most is van népirtás. Sajnos! 
Vélemények a kultúra fogalmáról, szerepéről, befolyásoló, meghatározó feltételeiről. A kultúra fogalma: az ember és ember kapcsolata, amelyet az emberi mú, az ember által alkotott „objektivációk" értékek közvetítenek. Egyaránt beletartozik a szúkebben vett kultúra: a nyelv, a tudomány, a múvészet, a hit, a vallás, valamint az ember magatartása, életmódja, beleértve a lakáskultúrát, az öltözködést és étkezést, az ember alakította környezetet. Ezek valamennyien összefüggnek. A társadalom kulturális, szellemi tőkéje és az életmód, a tudás, a közösségek, az ipar, a demokrácia, a múvészet, a közmúvelődés - szórakozás. Mennyi értéknek van tehát köze az emberhez, az értékeknek pedig emberhez, emberiséghez, a kultúra az ember „szubjektum” viszonya az "objektumhoz", az ember viszonya az általa megformált világhoz. A kultúra három vagy négy ágazatot foglal magában: az anyagi, a társadalmi (esetleg a politikai), és a szellemi kultúrát - a szellemi termelési módot amelynek egyik bázisa az értelmiség - . A kultúra Bourdieu (1986) szerint három dolgot jelent : 1) belsővé tett személyes tudást, készséget, 2) tárgyiasult formát mint mű, objektiváció, 3) az intézményt.

\section{6. Örsi Julianna 2015 Parasztvilág.} Parasztársadalom. ${ }^{9}$

A Jászkun parasztság tárgyi és személyi kultúrája, tudása, öntudata, munka, életmód, tárgyi eszközei, intézménye a család.

A kultúra tehát (Csányi) a tudás, a hit, az érdekek, a szimbólumok, a nyelv, a gondolkodás, a megformálás, szemléletünk, cselekvésünk, formálódásunk világa. Az anyagi - szellemi kulturális, múvelési, múvelődés világa, mindezekkel az értékekkel való azonosulás - identitás és a mentalitás világa. $\mathrm{S}$ ezekkel történő rendelkezés, bírás különböző szintjén - fokán áll - él az ember, ami minősíti is értékét, minőségét.

\section{Marx Károly (1961) A tőke I. A politikai} gazdaságtan bírálata. ${ }^{10}$

Mi köze van Marxnak s fő nagy múvének a Tőkének az anyagi - szellemi javak - értékek összességét tartalmazó kultúrához? Igaz-e, hogy a kultúra országútján járt, jött létre ez a nagy mú, amelyben a szerző összegyújtötte feldolgozta Anglia - Nagy Britannia polgári társadalom-történetének négyszáz éves tapasztalatait, a tôke termelési folyamatainak természeti - társadalmi törvényszerűségeit, a gazdasági formák: az áru, az érték, a munka, a termelési mód, a termelési viszonyok, az ősi, magukat túlélt termelési módok és a velük járó anakronisztikus társadalmi és politikai viszonyok állapotait. Az én kutatásom tárgya e múben - írta a szerző - a tőkés termelési mód és az ennek megfelelő termelési és forgalmi viszonyok. A tőkés termelés klasszikus hona Anglia, ezért választottam föleg ezt az országot, ám rólad is szól a mese Németország. E mú végső célja a modern társadalom gazdasági mozgástörvényének feltárása, ezekről a vas törvényszerūségekről érvényesülő tendenciákról van szó. De személyekről itt csak annyiban van szó, amennyiben azok gazdasági kategóriák megszemélyesítői, meghatározott osztályviszonyok és érdekek hordozói. Ezek a kategóriák mai ismereteink szerint értékek hordozói (értékek, értékszubsztanciák, érték tárgyiság), értékhordozója valamilyen használati érték kell legyen, az érték -listán társadalmi kategória, a tőkévé vált érték, arra a tulajdonságra tett szert, hogy értéket hozzon létre (pénzt) az értéke értéktörvény, az érték nagysága, az értékforma, értéktermelés, az értéktöbblet - megannyi tényező amely a mindenkori kultúrával összefügg, benne van a társadalom kultúrájában az emberben, ha az 
ember a kultúrában - kultúrából is szocializálódott.

De Marx az értéket a munkából eredezteti, ott a munka nem érték, hanem az érték forrása, eredője, az ember nembeli lényegének egyik nagyon fontos része, eleme. Számos emberi munka, emberi tevékenység szükséges - fontos, hasznos, de nem hoz létre értéket, értéktöbbletet.

A kultúra, mint szellemi termelési mód - Marx utáni hipotézis.

Többféle vélemény, gondolkodás, elgondolás és ma a világban és hazánkban is a szellemi termelési módról, arról, hogy más-e az anyagi termelési mód kultúrája, logikája, értékrendje, gondolkodása, mint a szellemi termelési módé. A mezőgazdasági tőke, a kereskedelmi tőke, az ipari tőke, a pénztőke még itt nem forradt össze a tudástőkével, ma pedig a tudás tőke lett (lesz) a legnagyobb húzóerő - egy tudásalapú társadalom építésében, ez az ásványkincs, de itt még ez kevésbé a szellemi termelési mód. A tudás értéke nagyon relatív, mert itt még alig mérték az érték, az érdek vagy érték vita hiányzik, nem tisztázott milyen érdeket, milyen értéket hordoz létében az ember. (Jászságban a parasztság megszűnőben van, a munkásság nem szerveződött osztállyá, a szegénység kultúrája tovább él - oka lehet szociális, kulturális, lélektani, szellemi - a szellemi termelési mód, fontos bázisa lehet a megye értelmisége, attól függően, hogy az értelmiségnek milyen önértéke, milyen inteligenciaszintje van, tanul-e, múvelődik-e holtáig, mint a jó pap, s hogy a lakosság hány százaléka olvas?) A tudás, a szellemi termelési mód, a családi, iskolai, települési szocializálódás nem független a kultúrától, politikától, gazdálkodástól, szociális környezettől, amelyben az emberi élet zajlik, amit kultúrának nevezünk.

\section{Kertész Imre, Közös nyelvünk a kultúra! ${ }^{11}$} Vázlat

- Veszélyek, hamis tudat: tudatlanság, tájékozatlanság, szolidaritás hiánya, indulatok

- Hagyni kéne alkotni egymást, játszani is engedd fiadat

- Nincs elég pénz a kultúrára

- Értékvesztés, EU-n túl lehet-e élni?

- Elitre van szükség, jó kormányzásra, jó kormányzókra?

- Az ifjúság megy!

- Az Európa eszme is: tudás, alkotás, gondolkodás

Nevelés, a genetika, a szocializáció-e a meghatározó érték-tényező? Izgalmas kérdés, hogy a nevelés vagy a genetikai örökség játszik meghatározóbb szerepet az ifjak felnövekedésében. Mára a vita eldőlt, mert nyilvánvalóvá vált a két oldal egymásrautaltsága és összjátéka a felnövekedés folyamatában. A nevezett két oldal függvényében, történetileg a kultúrák értékei, szokásai, gyakorlatai, intézményei határozzák meg az emberi felnövekedés módosulásait mind az aktív cselekvő oldalon, mind a passzív, szenvedő oldalon, ahol a szocializációs különbségek, az identitás és a mentalitás funkciói - szintjei, mindhárom tényező világa determinált és determinál. A modern mentalitás elterjedésére nagy szükség van! Ez hosszú és húzós folyamat eredménye, itt most csak értékeinek felsorolására van lehetőség.

Ezek: racionális gondolkodás, egyéni felelősség vállalás, társadalmi, politikai, gazdasági 
környezet aktív alakítására való törekvés, tolerancia és normák, szabályok követelése.

\section{Csepeli György, ${ }^{12}$ A modern identitás - az azonosulás világa: \\ - Idem esse \\ - A személyes identitás \\ - A kollektív identitás \\ - Identitás és helyzet \\ - Az identitás hiánya \\ - A meghasadt identitás}

A kulturális értékekhez való hozzáférés lehetőségei - jogai - kötelességei, formái, nehézségei. (Csepeli)

Nehéz feladat az értékekhez való hozzáférés azért is, mert: negatív, nemi, nemzeti, személyes, társadalmi, társas és vallási identitás is létezik a társadalomban, kultúrában, politikában, gazdálkodásban, tudományban stb. $A z$ értékek pedig soha sem figyelhetők meg közvetlenül, így vagy az értékítéletek által átitatott vélemények, nézetek, attitűdök megfigyelése vezethet eredményre, vagy az értékvezérelt viselkedés alapján történt következtetés nyújthat támpontot, a különböző kulturális anyagi - szellemi javakhoz, értékekhez. Az értékek alanyai egyének, családok, társadalmi csoportok, alrendszerek hozzáférhetnek, hozzájuthatnak értékek-hez, ha ez joguk, kötelességük; igen ám, de mikor és hogyan? „Ha valaki dudás akar lenni, pokolra kell annak menni", ha két dudás nem fér meg egy csárdában, ha két párt vezére egyszerre akar miniszterelnök lenni? Melyik szenvedi meg a negatív identitást? Az ember a kultúrákban is, „Szubjektum”, individuum többféle társadalmi lény alanya, szereplője, esetleg szerzője: kulturális én, politikai én, gazdálkodási én, erkölcsi én, vallási én, tudományos én, esztétikai lény stb. Minden életvilág értékeinek megismerése, múvelése a modernizálódott társadalomban kultúra eszközeivel, képességekkel ellátni, az önépítést folyamatosan biztosítani igen húzós, fáradságos feladat.

\section{Hankiss Elemér 2005. Az ezerarcú Én ${ }^{13}$}

Civilizációs hatások, korrupciók, stratégiák, személyiségre ható tényezők, szabadság közjó, az autonóm én, társadalmi identitás értékei - szintjei, a modern társadalom kulturális - értékvilágai.

A civilizációs hatások a személyiségre ható tényezők, a személyes emberi lét, abszolút érték. A kulturális értékekhez való hozzáférést megnehezíti az is, hogy a múvelési múvelődési koncepciók - stratégiák készítésénél elveszhetünk az „énről” szóló fogalmak, kategóriák, hipotézisek, elméletek, tudományok dzsungelében. (Az erkölcsi alany - például - ha nem viselkedik erkölcsi lényként - ha rossz, ha nem tisztességes, ha öl - lop - hazudik stb. bekövetkezhet az Én bukása.) Köztudott tény: az adott kultúra és civilizáció látja el az embereket azokkal az eszközökkel, amelyekkel formálhatják környezetüket és önmagukat ennek a társadalmi mozgásformája a magatartás. Ennek a tevékenységnek szakemberei a kulturális antropológusok, pszichológusok, szociológusok, etológusok ismerték fel azt a lehetőséget hogyan segítik, ösztönzik, akadályozzák az embereket énjük alakításában. A személyiségre ható tényezők: a patológia, fejlődéslélektan, nyelv, beszéd, kommunikáció, emberi kapcsolatok, nők és férfiak, az életkor, társadalmi és politikai környezet, történelmi változások, szépirodalom megannyi tényező vehet részt az önépítési kultúra alakításában. A kulturális - civilizációs környezet egyúttal az egyéni szabadság fontos forrása is. Ám a személyes emberi lét abszolút érték, önmagában hordja célját és értelmét (Charles, Taylor 1989.). Legfőbb érték az autonóm én, még ma is az emberi értékek és a 
társadalmi innováció legfőbb forrása (Levin). A népi királyok, grófok, bárók, hercegek, arisztokraták sok helyen eltúntek. Az új világrendben a tömeg az úr. Nem néhány embert kell meggyőzni az új értékrendek értékességéről, a közjó igazságosságairól, hanem milliókat és százmilliókat. De látnunk kell, nem vagyunk teljesen szabadok szerepeink, énjeink, magatartásunk kiválasztásában. Társadalmi és kulturális normák, szabályok, törvények határolják be autonómiánkat. Rabjai, röghözkötöttjei vagyunk annak a társadalomnak (Jászkunságnak, Tiszazugnak) kultúrának, korszaknak, falunak, városnak, amelyekben élünk. $A z$ én és társadalomépítés modelljeit, magatartásformáit, tipológiáit is hozzá kell igazítani életfeltételeinkhez. A modern társadalomnak megfelelő program szerint lehet és szükséges szocializálódni, integrálódni a kulturális érték és érdekvilágnak is. Megfelelő kultúrák fontosak, mert képesek közösségeket létrehozni, jól múködtetni.

A társadalmi identitás értékei: Hűség, Bizalom. Otthonosság, Barátság, Büszkeség, Hazafiság, Internacionalizmus, Odaadás, Szolidaritás A társadalmi identitás szintjei: Család, Barát kör, Szomszédság, $A z$ együttes élmény, Lokalitás, Kommunalitás, Helyi társadalom, Történeti táj - régió, Földrajzi helyzet, Nemzet, Eszmék, ideológiák, ideálok, Jog és erkölcs

11. Bozóki András (2012) A magyar demokrácia válsága. Virtuális köztársaság. A kultúra a szimbólikus politika fogságában ${ }^{14}$

Ez a tanulmány az Orbán-rendszer kultúrpolitikáját a rezsim egészének kontextusában értelmezi. Itt a kultúrpolitika nem tekinthető „ágazati politikának”. A terület élére kinevezett káderek azt teszik, amit a miniszterelnök elvár tőlük, a kulturális pozíciók elitcseréje, a radikális elitváltás, olykor következménye

egzisztenciális kiszolgáltatottság. A kultúra olyan terület, amelyet lehetetlen totálisan kontrolálni, lényegéhez tartozik a sokféleség (sokféle kultúra, kultúrák léteznek) az alkotói és értelmezői autonómia, a megszokott eltérő gondolkodásmód, a maffia állam és a nem maffia állam más és más ethosza. A kulturális adminisztrációt le lehet cserélni, de az "objektív" kultúrát nem lehet szimbolikus politikával helyettesíteni, miként az értékrendeket sem, az egyenlőségeszményeket, a szabadságeszményt sem.

Ennek a kultúrpolitikának jellemzői:

- A törzsi fogalmak visszatérése „munka”, az „otthon”, a „rend”, a „nemzet” és a „család" - ezek az új rendszer hívószavai lettek.

- A szuverenitás fontosabb, mint a demokrácia

- A kultúrpolitikát felváltotta a kormány szimbolikus politikája

- A rendszer építőkövei: a maffia állam ethosza - megszerezni, kiszorítani

- A „centrális erőtér”, a „nemzetegyesítés”, elitváltás

- Kultúrharc helyett harc a kultúra ellen

- Intézmények birtoklása, politikai lojalitás megvásárlása, szellemi gettóba zárás (Marx) A kultúra gyarmatosítása, a magas kultúra és alkőtó személyiségeinek leértékelődése, kivándorlása.

\section{László Ervin (2008) Világváltás. A Holosz} kultúrája. ${ }^{15}$

Megérett a helyzet egy újabb változásra: a Logosz civilizációjából a Holosz civilizációjába való átmenetre. Vannak olyanok, akik már ma is holisztikus kultúra szerint élnek. Ebben a kultúrában az emberek újragondolják, mennyire fontos számukra az értékrendjüket, viselkedésüket a fogyasztás felől a minőség felé 
Fenntartható fejlődés a XXI. században

irányítani. Ezek a változások gyorsak és - áttérés a tekintélyen alapuló külső forradalmiak. Fontos megvonni a bizalmat indítékokról a belső tudáson alapuló mindenkitől, aki nem fogadja el a jelenlegi indítékokra értékrendet. Új kultúra kialakulása, új kultúra az - áttérés a széttöredezettségről a teljességre Egyesült Államokban. Egy reményteljes szubkultúra indult gyors növekedésnek ott:

- a fenntarthatóság, az egészséges életmód, a személyiség fejlesztés

- áttérés a versenyről az együttmúködésre

- áttérés a mohóságról, az elégedetlenségről

- áttérés a "modernitás”, „kulturális az elégedettségre a dolgok megbecsülésére kreatívak", a "modernnek" az önszerveződők értékeinek gyarapítása felé.

\section{IRODALOMJEGYZÉK}

[1.] Andorka Rudolf (1996) Merre tart a magyar társadalom. Antológia Kiadó. Lakitelek. 80-87.

[2.] Spíró György (2012) Miért hagytuk, hogy így legyen? XXI. Század Kiadó Kft. Budapest. 170176.

[3.] Zygmunt Bauman (1967) Általános Szociológia. Kossuth Könyvkiadó. Budapest. 11-24.

[4.] Magyar Értelmező Kéziszótár (1828) Akadémiai Kiadó. Budapest (2003.) 774.

[5.] Csányi Vilmos (1999) Az emberi természet. Vince Kiadó. Budapest. 246.

[6.] Csányi Vilmos (2006) Az emberi viselkedés. Sanoma Könyvkiadó. Budapest. 223-227.

[7.] Hankiss Elemér (2005) Az ezerarcú Én. Osiris Kiadó. Budapest. 361-365.

[8.] Vitányi Iván (2007) Új társadalom - Új szemlélet. Napvilág Kiadó. Budapest. 45., 170.

[9.] Örsi Julianna (2015) Parasztvilág. Túrkevei Kulturális Egyesület Kiadó. 126-129.

[10.] Marx Károly (1961) A tőke I. Kossuth Könyvkiadó Budapest. 523-706.

[11.] Kertész Imre (2007) Közös nyelvünk a kultúra. 168 óra. 2007. V. 10.

[12.] Csepeli György (2014) Szociálpszichológia mindenkiben. Kossuth Könyvkiadó. Budapest. 339-357.

[13.] Hankiss Elemér (2005) Az ezerarcú Én. Osiris Kiadó. Budapest. 53.

[14.] Bozóki András (2012) A magyar demokrácia válsága. Gondolat Kiadó. Budapest. Élet és Irodalom. LVI. évfolyam 2. szám. 2012. január 13.

[15.] László Ervin (2008) Világváltás. A változás harmonikus útja. Nyitott Könyvmúhely. Budapest. 105-112. 